\title{
Sodium Fluoride Toxicity on Blood Parameter and Catalase Activity of Indian Fresh Water larvicidal fish Channa straitus
}

\author{
ARUN CHAUHAN, HARPREET SINGH and RAHUL SINGH* \\ Department of Zoology, School Of Biotechnology and Biosciences, \\ Lovely Professional University, Phagwara, Punjab- 144411, India.
}

http://dx.doi.org/10.12944/CWE.9.3.48

(Received: June 11, 2014; Accepted: October 14, 2014)

\begin{abstract}
Due to its high reactivity fluoride does not occur in the element state in nature. WHO and ISO 10500 recommend that the fluoride content in drinking water should be in the range of 1.0-1.5 $\mathrm{ppm}$. Fluoride ions are directly toxic to aquatic life and accumulated in the tissues where absorption rates exceed excretion rates. Duration of exposure also affects toxicity. Snake headed fish (Channa straitus) is larvivorous and edible fish species of India and South East Asia. After exposure of NaF $(60 \mathrm{ppm})$ it has been observed that body weight and organosomatic index has been decreased significantly. Some leucocytes also decreased i.e. Neutrophils $1.125-2.68 \%$, Monocytes $0.66 \%$ $35.66 \%$. But Lymphocytes $2.9-10.01 \%$ and eosinophils $7.6-20.88 \%$ increased. $\mathrm{Hb} \%$ also decreased. After estimation of Catalase activity it has been observed its activity is increased in liver may be associated with increased oxidative stress. Catalase activity is decreased in brain $0.03 \%-9.23 \%$.
\end{abstract}

Key worlds: Sodium Fluoride, Channa striatus, Leucocytes, Catalase.

\section{INTRODUCTION}

Due to its high reactivity fluoride does not occur in the element state in nature. It exists either as inorganic fluorides (including free anion F) or as organic fluoride compounds. In the global environment inorganic fluorides are much more abundant than organic fluoride compounds. Natural sources of inorganic fluorides are weathering, volcanoes activity and marine aerosols.

WHO and ISO 10500 recommend that the fluoride content in drinking water should be in the range of 1.0-1.5 ppm. Fluoride occurs naturally in public water systems as a result of runoff from weathering of fluoride containing rocks leaching and soil into ground water. Atmospheric deposition of fluoride containing emissions from coal fired power plants, agricultural fertilizers and industrialization (aluminum, steel and glass). The concentration of fluoride ions is significantly increasing in aquatic ecosystems as a consequence of many industrial activities. Sodium fluoride is an odorless white powder or colorless crystals with a water solubility of $4 \%$ at $15^{\circ} \mathrm{C}$. Fluoride ions are directly toxic to aquatic life and accumulated in the tissues where absorption rates exceed excretion rates. It induces histopathological changes and also causes oxidative stress. Duration of exposure also affects toxicity. Snake headed (Channa straitus, Bloch) is larvivorous and edible fish species of India and South East Asia.

\section{MATERIALS AND METHODS}

Total forty adult species of Channa straitus having an average length of $5 \mathrm{~cm}$. and weight of 10 $\mathrm{gm}$. were collected from local fish farm. All individuals were acclimatized under laboratory condition for 21 days. During acclimatization the fish were fed with the prepared market feed. After acclimatization the fish were divided into two equal groups of twenty each into well equipped aquaria of 75 lit capacity. One group was exposed to a sub lethal dose of 
$60 \mathrm{ppm} \mathrm{NaF}$ for 20 and 40 days, applied on every alternate dose while the other group was maintained as control. To maintain the water quality the aquarium water was changed for every alternate day. Beside these antifungal (Flucanozole) and antibacterial (Oxtetracycline) used to prevent the bacterial infection. Live food (worms) was added at an interval or regular basis.

The body weight of each animal was noted before treatment and also noted on day of 20 and 40. Organosomatic index (OSI) was calculated by the following formula-

OSI= wt. (gm) of organ/ Total body weight $\times 100$

For study of hematological change blood collected with the help of insulin syringe from cardinal vein after anesthetized the fish. TLC was studied by using Neubauer's chamber (Daice and Lewis, 1977). DLC was studied by use of Leishmann stain and method was given by Daice and Lewis (1977). $\mathrm{Hb} \%$ was studied by use of haemometer.

Catalase enzyme activity recorded by Luck (1977) method. $3.0 \mathrm{ml}$ reaction mixture $(50 \mathrm{ml}$ Potassium Phosphate buffer- $\mathrm{pH} 7,1.25 \times 10^{-2} \mathrm{M}$ Hydrogen peroxide and an appropriate amount of cytosolic supernatant) observed at $240 \mathrm{~nm}$. The enzyme activity was unit represents $\mu \mathrm{mol} \mathrm{H}_{2} \mathrm{O}_{2}$ decomposed minut ${ }^{-1} \mathrm{mg}^{-1}$ protein.

\section{RESULTS AND DISCUSSION}

After the examination of body weight of $\mathrm{NaF}$ treated fish after 20 days and 40 days exposure, body weight decreased significantly from $6.49 \%$ to $18.80 \%$ respectively as compare to the control. After the calculation of organosomatic index of $\mathrm{NaF}$ treated fish after 20 days and 40 days exposure, index has been decreased significantly from $8.1 \%$ $16.66 \%$ of liver and $4.3 \%-16 \%$ of brain, respectively as compare to the control.

After the examination of total leukocyte of $\mathrm{NaF}$ treated fish after 20 days and 40 days exposure, TLC increased significantly from $0.13 \%-5.37 \%$ respectively as compare to the control.

After the examination of Differential leukocytes of $\mathrm{NaF}$ treated fish after 20 days and 40 days exposure, DLC has been changed significantly respectively as compare to the control, Neutrophils decreased $1.12 \%-2.68 \%$, Eosinophils increased $7.6 \%-20.88 \%$, Monocytes decreased $0.66 \%$ $35.66 \%$, Lymphocytes increased $2.91 \%-10.01 \%$. In the present study, lymphocyte and eosinophils increased but neutrophils and monocytes decreased with increasing concentration of sodium fluoride and also duration of exposure. The increase in number of lymphocytes and study fall in neutrophils in chemically stressed fishes have been reported by several workers. (Pathak et. al., 2013).

The decrease in the percentage of monocytes and neutrophils were observed after exposure to different chemicals in fishes. (Benerjee et. al. 2010; Devi et. al. 2008).

Neutropenia (decrease in neutrophils $27.71 \%$ ) in fluoride induced fishes are due to haempoietic depression and causes aplastic anemia. Neutropenia is the result of failure of the bone marrow to produce adequate number of neutrophills are from excessive peripheral destruction or consumption of these cells. Neutropenia is more often the result by the development of an idiosyncrasy towards a particular compound which binds to surface of leucocytes acts to form an antigenic complex, resulting antibodies being capable of destroying or damaging the circulatory leucocytes and their more mature precursor in bone marrow. Thus in the present study, neutropenia might be due to its toxications on the haemopoietic organs.

The significant decrease monocytes in fluoride induced fishes are the result of movement of these cells at the site of inflammation resulting in monocytopenia (Sharma et. al. 1984).

After the examination of hemoglobin percentage of $\mathrm{NaF}$ treated fish after 20 days and 40 days exposure, $\mathrm{Hb} \%$ decreased significantly from $4.87 \%$ to $12.30 \%$ respectively as compare to the control. Anaemic conditions appear to be a common effect of sodium fluoride. Anemia could be attributed to increase destruction or loss erythrocytes and/or suppression of erythropoiesis by fluoride .It may also be due to haemodilation caused by disturbed osmoregulations. Leukocyte count increases due to the tissue damage and subsequent removal of 


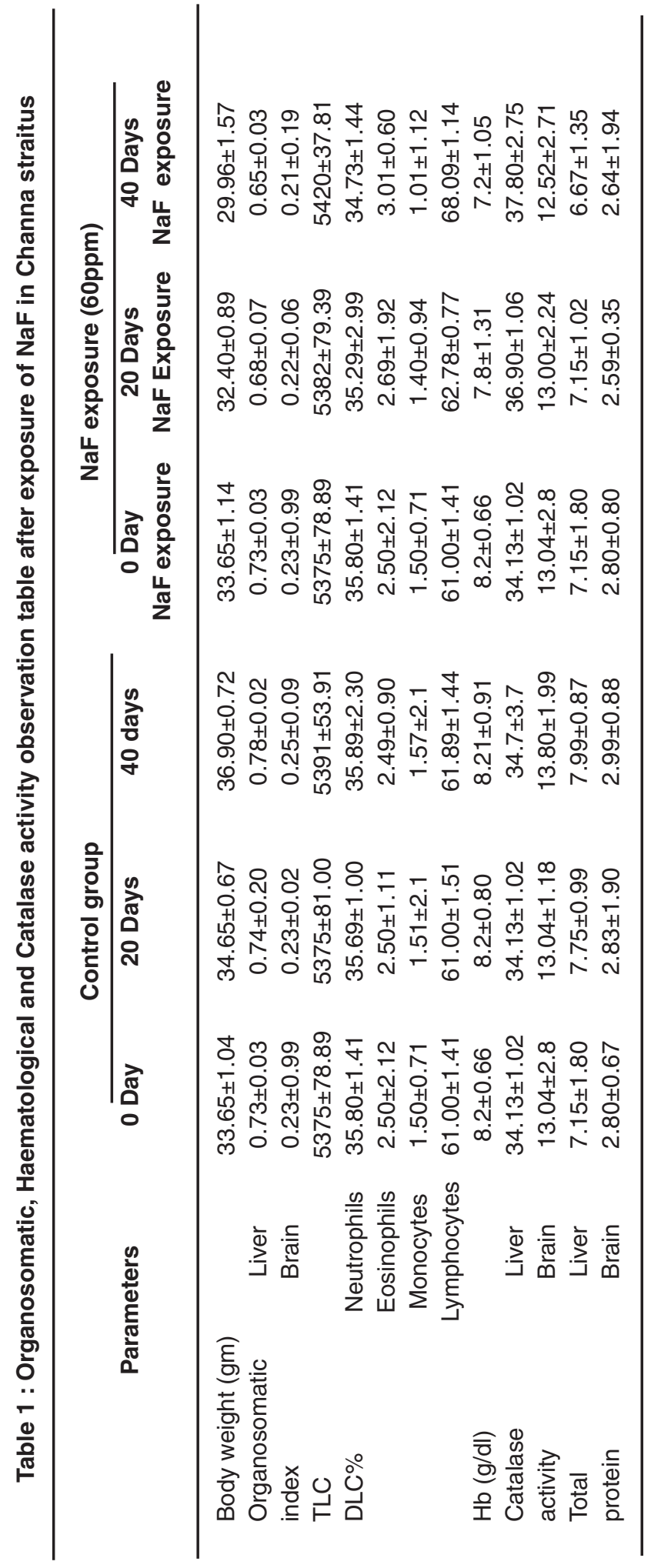


cell debris. WBC's plays a great role during tissue damage by stimulating the haemopoietic tissues and the immune system by producing antibodies and chemical substances working as defense system.

After the examination of catalase activity in liver and brain of $\mathrm{NaF}$ treated fish after 20 days and 40 days exposure, catalase activity significantly increased from $8.11 \%-8.9 \%$ in liver and decreased $0.03 \%-9.23 \%$ in brain respectively as compare to the control.

After the examination of liver and brain of $\mathrm{NaF}$ treated fish after 20 days and 40 days exposure, total protein decreased significantly from $7.74 \%-16.40 \%$ in liver and $8.24 \%-11.48 \%$ in brain respectively as compare to the control.

An increase activity liver compared to other tissues which are in agreement with their literature (Hidalgo et al., 2002; Gul et al., 2004). In our study, sodium fluoride the increase CAT activity may be associated with increased oxidative stress by the sodium fluoride. Increase in antioxidative enzyme activities with laboratory exposure to a variety of organic and metal contaminants were observed but the responses were variable for different species. In previous studies the liver was found to be stronger to face of oxidative stress than the other tissues and a uniform organ with the highest antioxidative enzyme activities (SOD, CAT). This could be related to the fact that the liver is the site of multiple oxidative reaction and maximal free radical generation (Gul et al., 2004; Avci et al., 2005).

Inhibition of CAT activity was observed in brain tissue depending on the concentration of sodium fluoride. The brain is very susceptible to oxidative damage through free radicals as it contains high amounts of unsaturated lipids and utilizes about $20 \%$ of total oxygen demand of the body. While CAT is highly active in the liver, the brain is not particularly enriched in antioxidant enzymes. It was determined that CAT activity was found to be maximum in liver and minimum in the brain of seven animal species (Jena et al., 1998).

\section{CONCLUSION}

Fluoride is toxic agent when ingested in more than recommended dose. It accumulates in gill, liver, brain and kidney. Against it's effect body produce more specific enzymes and leucocytes.

\section{ACKNOWLEDGMENT}

Thanks to Zoology Department of Lovely professional University to encourage us and provide laboratory facilities.

\section{REFERENCES}

1. Report: World health organization. Geneva, Fluorine and fluorides, 1984.

2. Book: Dacie, J. V. and Lewis. Practical hematology. ELBS and Chorchill, Livingstone, 5: 87 (1977).

3. Book: Luck, H., Methods of enzymatic analysis edited by Bergmeyer, H. W. Academic press, 1963, New York, section 3.

4. J. Chen, J. Cao, J. Wang, R. Jia, W. Xue, Y. Li, Y. Luo and L. Xie. Effect of fluoride on growth, body composition, serum and biochemical profile in a fresh water teleost, Cyprinus carpio. Environmental Toxicology and Chemistry, 32: 2315-2321 (2013).

5. Lalit Pathak, R.S. Saxena and H.N. Sharma. Haematological changes in major Indian carps under stress of malathion and parathion. Ind J Biol Res. 2(2): 112-120 (2013).

6. G. Benarjee, B. Narayana Rao, K. Srikanth and G. Ramu. Haematological changes in the fresh water fish Channa punctatus due to the effect of Rayon Industry effluents. EM International, 29(1): 63-68 (2010).

7. P. Devi, D. Baruah, B.K. Baruah and A. Borkotki. Impact of endosulfan on some haemotological parameters of Channa punctatus (Bloch). Poll Res. 27(3): 485-488 (2008).

8. Hidalgo, M. C., Exposito, A., Palma J. M., and Higuera M. Oxidative stress generated by dietary Zn-deficiency: studies in rainbow trout (Oncorhynchus mykiss). Int. J. Biochem. 
Cell Biol., 34: 183-193 (2002).

9. Gul S., Belga-Kurutas E., Yiliz E., Sahan A., Doran F., Pollution correlated modifications of liver antioxidant systems and histopathology of fish (Cyprinidae) living in Seyhan Dam Lake, Turkey. Environ. Int, 30: 605-609 (2004).

10. Avci A., Kacmaz M., Durak I., Peroxidation in muscle and liver tissues from fish in a contaminated river due to a petroleum refinery industry. Ecotoxicol. Environ saf., 6: 101-105 (2005).

11. Sharma M. L., Aggarwal U. P., Kalpana and
Sandhya, Effect of lithium on haematology of $H$. fossilis, Environ. Biol interaction proc. Symp. 19-20 (1984).

12. Jena B. S., Nayak S. B., Patnaik B. K., Age related changes in catalase activity and its inhibition by Manganese(II) chloride in the brain of two species of poikilothermic vertebrates. Arch. Gerontol Geriatr, 26: 119129 (1998).

13. Rahul singh, K. K. Ansari and Sadguru Prakash, Effect of sodium fluoride on haematology of fresh water teleost, Catla catla. Aquacult, 12(2): 191-193 (2010). 